\title{
Improving Competitive Advantage of Chinese Sports Brand through Brand Management
}

\author{
Chuming Hu \\ Management School, Jinan University, Guangzhou, China \\ Email: thuchum@jnu.edu.cn
}

Received 4 March 2015; accepted 12 April 2015; published 17 April 2015

Copyright (C) 2015 by author and Scientific Research Publishing Inc.

This work is licensed under the Creative Commons Attribution International License (CC BY).

http://creativecommons.org/licenses/by/4.0/

(c) (i) Open Access

\begin{abstract}
Along with the advance of domestic sports undertakings, China's sports goods industry has shown great potential for development. This paper analyses the present situation of sports brand marketing in China. The result shows that in the process of sport marketing, domestic sports brands have acquired some certain achievements. But at the same time, many serious problems are beginning to emerge. They are as follows: a vague positioning, the lack of long-term planning, irrational development model, and insufficient marketing methods. In order to enhance the market competitiveness of the domestic sports brand, there is an urgent need to implement brand management. Attention should be focused on nailing down brand positioning, setting up the brand characteristics, and cultivating brand.
\end{abstract}

\section{Keywords}

Sports Brands, Sports Marketing, Competitive Advantage, Brand Management

\section{Introduction}

China's sporting goods industry has experienced sustained and rapid development in recent years. At the end of 2012, China's sporting goods industry reached 176 billion yuan, accounting for more than $80 \%$ of the overall proportion of the sports industry [1]. In the past several years, the number of sporting goods stores goes up with an average annual rate of $10 \%$, sales goes up with an average annual rate of $10 \%$. Due to the successful hosting of the Beijing Olympic Games, the sports brand in China has entered a period of rapid development in the 20072010.

With the great opportunity of the Beijing Olympic Games, the domestic sports brand developed rapidly. The 
enterprise value of Li Ning, Anta, 361 ${ }^{\circ}$, Jordan, Xtep, Erke, Deerway got rapid growth. In 2009, the income scale of Chinese local sports brand Li Ning even exceed the international sports goods giant Adidas, jumping to second in the sporting goods market in China. At the same time, the domestic brand is gradually narrowing the gap with industry leader Nike.

\section{The Present Situation of Sports Brand Marketing in China}

\section{A. The product strategy of the Chinese sports brands}

Chinese sporting goods market dominated by the footwear and clothing [2]-[4]. Some brands mainly in the production of sports shoes brand, such as Erke, Qianda, Guirenniao, Fushilai and Kangda. Brands mainly in the production of sports clothing and footwear are $361^{\circ}$, Deerway, Saiqi and Kangwei. Brands mainly in the production of special sports are Peak and Voit, targeting at professional basketball shoes and basketball products. Li Ning, Anta, Xtep are comprehensive sporting goods brands, including sportswear, sports shoes and sports equipment. Table 1 shows the specific market segments of the major brand products.

\section{B. The pricing strategy of the Chinese sports brands}

The price of various sporting goods brand in the sports apparel market broadly divided into three levels: Nike, Adidas, Kappa, Puma and other international brands occupy the high-end market, the market price of about 400 yuan/piece. The mid-market is mainly occupied by Anta and Li Ning, the domestic first-line sporting goods brands, priced at around 200 to 400 yuan/piece. The low-end consumer market (the price less than 200 yuan/ piece) is mainly occupied by domestic second-tier sporting goods brands, such as XTEP, peak, $361^{\circ}$ and Erke.

\section{The channel strategy of the Chinese sports brands}

Domestic sports brand marketing channels mainly in the franchise and specialty stores. In recent years, the domestic sports brand has taken a regional agency and retail franchise system, self-built terminal channels, building a huge marketing network, and constantly strive to improve market share [5].

$\mathrm{Li}$ Ning, Anta, $361^{\circ}$ and Xtep experienced from the distributor, branch to the development of the self-built channels. From the occupation of third-line market to the second-line market, Li Ning and Anta have entered the first-line market. As of June 2012, Li Ning has owned 7300 stores in the country. Li Ning established the most comprehensive, covering first, second, third-tier cities' network marketing, become the leader of the sporting goods industry.

\section{The publicity strategy of the Chinese sports brand}

\section{(1) Sponsoring sports events}

Sport sponsorship is used to support marketing objectives, such as enhancing brand image and increasing consumers' intentions to purchase product or service [6]. In recent years, the domestic sports brands have sponsored many domestic and international sporting events or sports teams. Chinese sports brands often appear in the large-scale sports event. The major international sporting events can not only enhance the visibility of the enterprise, show the brand's competitiveness, but also create a lot of hidden opportunities, greatly enhance the brand's visibility and influence. Sponsoring sports events is of great help to enterprises to establish a good brand image (Table 2).

Table 1. The specific market segments of the relevant brands.

\begin{tabular}{ccccc}
\hline Product Category & Sports Footwear & Sports Clothing \& Footwear & Basketball Sports Products & Sporting Goods \\
\hline \multirow{2}{*}{ Brand } & Erke & $361^{\circ}$ & & Li Ning \\
& Qianda & Deerway & Peak & Anta \\
& Fushilai & SaiQi & Voit & Xtep \\
\hline
\end{tabular}

Table 2. Domestic sports brand sponsorship of sporting events.

\begin{tabular}{cc}
\hline Brand & Sponsorship of Sporting Events \\
\hline Anta & Sponsored China Basketball Association (CBA) Sponsored Chinese Women’s and Men’s Volleyball League \\
Erke & Sponsored International Women’s Tennis Tour Sponsored Snooker China Open \\
Li Ning & Launched the “Li Ning” China University Football League (CUFL) Sponsored Youth Basketball Tournament \\
Peak & Sponsored WTA Sydney Open Tennis Tournament Sponsored Mo Lila Hobart International Tournament \\
\hline
\end{tabular}




\section{(2) Using brand ambassador}

Now the use of image spokesmen to nurture the target consumer group is very popular in Chinese sporting market. Cultivation of sports brands target consumer groups needs the establishment of the brand. With the improvement of product quality, design of domestic sports brand, sports enterprise follow the usual way of international sports brand by using image spokesperson. Chinese sports enterprise hope to create loyal customer by the use of consumers' preferences for sports stars [6]. For example, the image spokesmen of Li Ning have O’neal, Lin Dan, Wu Minxia, Powell, Isinbayeva. The Brand Ambassador of Erke has Jordan Chan, Jang Nara.

\section{Problems That Facing the China's Sports Industry}

Behind the rapid prosperity, some crises may well be lurking. The enterprises do not pay attention to the positioning of the brand and product qualities in the process of blind and the rapid expansion [7]. These led to serious homogeneity of goods, and the domestic sports brand competition is also increasingly fierce [8]. With the Olympic opportunity is no longer, which increased the pressure on the stock of the domestic sports brand, brand influence weakened, product homogeneity serious questions are beginning to emerge.

According to the data of the sporting goods industry in China 2012 annual report shows, Li Ning in the first half of 2012, income of 3.88 billion yuan, a year-on-year decrease of $9.5 \%$, net profit of 0.44 million yuan, a year-on-year decrease of $84.9 \%$. Peak of the total income of 16.1 billion yuan, a year-on-year decrease of $28.5 \%$, net profit decreased by $43.3 \%$, but only 2.4 billion. The sales of Anta and $361^{\circ}$ are also negative year-on-year revenue growth, $-11.62 \%$ and $-9.95 \%$, respectively.

The major domestic sports brand Li Ning, Anta, $361^{\circ}$, XTEP, Peak, total inventory amount of up to 3.721 billion yuan, compared with the end of last year, the total inventory of 3.699 billion yuan, and an increase of as much as 0.22 million yuan.

In response to the difficult market situation, major domestic sports brands bring up the "austerity" policies to shrink the development scale. As the data shows that from early 2012 to the present, Li Ning had closed 1200 stores, Peak closed 1067 stores, the stores number of Anta also reduced 110.

Experienced rapid expansion after the Beijing Olympic Games and "extensive" development, domestic sports brands have entered the depth adjustment phase, the whole industry will usher in a major adjustment. At this point, the trend of industry consolidation is inevitable.

\section{The Problems Existing in the Process of the Development of Sports Brands}

\section{A. Vague market positioning}

From the perspective of brand marketing strategy, the domestic sports brand focus too much on short-term interests, and the lack of long-term strategic planning, especially in the link and positioning of the brand, the lack of consistency and stability [9]. For example, Anta company changed its spokesperson from table tennis players to basketball players, its flagship product positioning is more vague which is not conducive to their own brand image. Mature foreign brands are more advanced in this regard. For example, Nike Company, in the first, the product is based on the track and field running shoes, gradually positioning in basketball shoes and clothing, the spokesman for its products are always the NBA stars, for example, basketball star Michael Jordan, Vince Carter and so on. At the same time Nike mainly sponsor basketball games, reflecting the basketball features of its products. Compared to the domestic brand products is the lack of this feature and the flagship product.

\section{B. Lacking marketing methods}

Marketing tool plays a vital role in the process of maintaining and publicizing brand, extensive marketing tools will greatly enhance the brand's influence. The marketing of Chinese sports brand followed the traditional means such as advertising and celebrity endorsements [10]. Although these methods achieved some success, making the sports brand produce a certain influence in the community, the ratio of input costs to benefits is not the best [11] [12].

\section{Unreasonable development mode}

The present development mode of domestic sports brand concentrated on setting up stores. With the completion of the store layout, the total number of stores has saturated. With the increase in the number of stores, the single-store sales were affected. At last brings a series of questions, such as extensive management, rising costs, inventory increases, declining profits. 


\section{The Strategy for Chinese Sports Brands}

\section{A. Decreasing their positioning}

In order to change the current situation, it is a must to pay attention to adjust its product structure, improve product characteristics. Enterprises can adjust the product brand positioning to meet the changing needs of consumers, but the adjustments of brand positioning cannot be too frequent. Brand positioning should be consistency and continuity, too often brand positioning adjustment will be caused to the target consumer brand image blurred. Domestic sports brand is facing the dual pressures of both domestic and international markets, on the one hand, many of the domestic sports brand "fratricide" intense competition; on the other hand, the international sports brands such as Nike, Adidas is entering the second and third tier markets through low-cost strategy, which exert enormous pressure on the domestic sports brand. Therefore, the domestic brands need to find the right brand positioning, adjust product structure. The domestic sports brands can strengthen themselves by providing personalized products.

\section{B. Transform their business model}

The present development mode which just concentrated on the number of stores should be changed as soon as possible. Chinese sports brands should not eager for quick success and instant benefit by setting up stores. It is time for domestic sports brand to cultivate the proper sense of brand. The sports enterprises should enhance the profitability of a single shop by subdividing product lines, improving the channels, marketing, service and some other measures. Domestic sports companies should strengthen and update the understanding of the culture of its own brand, product attributes, target consumers.

\section{Develop multi-channel integration operations by combing with the current e-commerce}

With the rapid development of the current networks and new media, sports companies should focus on the effective use of e-commerce. E-commerce can reduce inputs in the marketing chain, reduce garment final delivery costs, thus forming a price advantage. The function of E-commerce is more important to strengthen the brand publicity.

\section{Improving the brand image}

From the long-term perspective, domestic sports brands should attach great importance to enhance the brand management and the adjustment of brand strategy. For example, setting up the brand characteristics which need to pay more attention to the market research and develop new marketing modes. Domestic sports brand can achieve brand personality by improving the product quality, process performance and technology. In the process of the implementation of brand management, it is necessary to adapt to the brand culture, and sports companies must be based on the long-term development goals.

\section{Conclusion}

Generally, this study offers a deep insight pertaining to the current situation of China's sports brand marketing. The results provide support for the notion that while many China's domestic brands have obtained some certain achievements through the process of sport marketing, some serious problems still exist and refrain the development of China's sports industry. As noted previously, a vague understanding of brand positioning, unreasonable development models, and the lack of long-term thinking and marketing tools, are mainly, the problems that threaten the future of China's sports branding. To get rid of such dilemma, change of brand management strategy is needed. A clearer branding positioning with specified brand characteristics and a more reasonable development model with multiple channels integration may be worth of trying. In addition, this study also suggests China's sports corporations to put more effort into the improvement of their brand images.

\section{Contribution}

The findings presented in the study make several contributions to the expertise of China's sports brand management. First, it provides an overall depiction of the situation of China's sports marketing by exploring the product strategy, pricing strategy and channel strategy of China's sports industry, which in turns, enriches the study of sports branding. Second, this paper expands the research of sports branding by discussing the potential factors that may limit the development of China's sports industry. It demonstrates that vague marketing positioning, lack of marketing methods and unreasonable development model are the major problems that China' sports industry needs to solve. Finally, this research expands the studies of China's sports branding by discuss- 
ing the methods that may be conducive to the future development of China's sports industry. It argues that to have the right brand positioning and brand image is the first step to take. It also suggests the development of a more rational business model can help China's sports industry walk out the dilemma it is facing.

\section{Limitations}

The limitations are as follow. First, as an effort to explore the way of improving Chinese sports brand through brand management, this study does not pay attention to the influence of consumers. In a marketplace where consumers' attitude becomes increasingly important to the development of a brand, a future study that includes the measurement of consumers' attitude and response toward China's sports brand may be helpful in terms of the management of China's sports brand. Second, although the research has provided several factors of the marketing strategy that China's sports industry currently applies, it does not explore those factors from an empirical perspective. Perhaps a future study can include interviews with CEOs of China's major sporting corporations so as to make the explanations more accurate and consolidate.

\section{Acknowledgements}

This study was supported by JNU Enterprise Development Institute Innovation Training Program of Guangdong Key Research Institute of Humanities and Social Sciences in Universities (Grant No. 2013CP004), and The Guangdong Soft Science Research Program (Grant No. 2013B070206034).

\section{References}

[1] Kaplan, S. and Su, L.D. (2012) Chinese Fandom and Potential Marketing Strategies for Expanding the Market for American Professional Sports into China. International Journal of Sports Marketing \& Sponsorship, $14,7$.

[2] Yan, Q. (2012) Study on the Marketing Strategy of Chinese Sports Brand. China Business \& Trade, 16, 54.

[3] Chen, X.M. and Ding, J.W. (2010) On Sport Marketing of Chinese Enterprises. Journal of Anhui Normal University (Natural Science), 2, 23.

[4] Carlson, J. and O’Cass, A. (2012) Optimizing the Online Channel in Professional Sport to Create Trusting and Loyal Consumers: The Role of the Professional Sports Team Brand and Service Quality. Journal of Sport Management, 6, 463-478.

[5] Apostolopoulou and Artemisia (2011) Ten Years of Integrating Research and Practice Perspectives: A Guide to Sport Marketing Quarterly Case Studies. Sport Marketing Quarterly, 4, 227-241.

[6] Pope, N.K.L. and Voges, K.E. (2002) The Impact of Sport Sponsorship Activities, Corporate Image, and Prior Use on Consumer Purchase Intention. Sport Marketing Quarterly, 2, 96-102.

[7] Kim, K. and James, J. (2013) Sport Marketing and Media Research: Contributions from the Global Network of Scholars in Sport Management. Journal of Global Scholars of Marketing Science, 23, 1-7.

[8] Lee, S. and Walsh, P. (2011) SWOT and AHP Hybrid Model for Sport Marketing Outsourcing Using a Case of Intercollegiate Sport. Sport Management Review, 14, 361-369.

[9] Qiu, X. (2009) Discussion on Hot Issue of Brand Endorser of Sports Star in China. China Sport Science and Technology, 41, 63-66.

[10] Jin, S. (2009) The Regional Brand of Sports Goods in Manufacture Industrial Clustering in China. Journal of Tianjin University of Sport, 41, 63-66.

[11] Huang, W.-W. (2009) Research on the Status Quo and Development of the Brand Management of Chinese Sports Goods Enterprises. Journal of Beijing Sport University, 9, 8.

[12] Hu, F.Y. (2006) Experience and Innovation of Sports Goods Brand Management in Our Country form Nike Mode. Journal of Sports and Science, 6. 